\section{Lembaran Sejarah}

Volume 14 Number 1

April 2018
ISSN 2314-1234 (Print)

ISSN 2620-5882 (Online)
Page

64-82

\title{
The Development and Character of Foreign Investment in Late Colonial Indonesia
}

\section{MARK VAN DE WATER}

Leiden University, The Netherlands

\begin{abstract}
This contribution discusses the development of private foreign investment in late colonial Indonesia. The increase in numbers of individual firms, their expanding volume and accumulation of investment in the Netherlands Indies are shown. The focus is on the years 1910-1940 and on Dutch foreign investment, although investment by other countries is touched upon in passing. The data used for this article originate from a database compiled from the Handboek voor cultuuren handelsondernemingen in Nederlandsch-Indië (Handbook for cultivation and trading companies in the Netherlands Indies) and will also be incorporated into my $\mathrm{PhD}$ dissertation entitled 'Foreign investment and colonial economic growth in Indonesia', which forms part of the larger research project 'Foreign capital and colonial development in Indonesia'.
\end{abstract}

\begin{abstract}
Abstrak
Kontribusi ini membahas pembangunan investasi asing swasta di masa kolonial akhir Indonesia. Kenaikan jumlah perusahaan individu, meluasnya volume, dan akumulasi investasi di Hindia Belanda diperlihatkan. Fokus artikel ini adalah tahun 19101940 dan investasi asing Belanda, meskipun investasi dari negara lain disinggung secara sepintas. Data yang digunakan dalam artikel ini berasal dari database yang dikumpulkan dari Handboek voor cultuur-en handelsondernemingen in NederlandschIndië (buku pegangan untuk penanaman dan perdagangan perusahaan-perusahaan di Hindia Belanda) dan juga akan dimasukkan dalam disertasi PhD saya berjudul 'Foreign investment and colonial economic growth in Indonesia' (Investasi asing dan pertumbuhan ekonomi kolonial di Indonesia), yang merupakan bagian dari proyek penelitian yang lebih besar 'Foreign capital and colonial development in Indonesia' (Modal asing dan pembangunan kolonial di Indonesia).
\end{abstract}

\author{
Keywords: \\ foreign \\ investment; \\ colonial \\ Indonesia; \\ foreign \\ companies
}

Kata kunci: Muara Angke, masyarakat perikanan, pelabuhan perikanan, pantai utara, Jakarta 


\section{Introduction}

Already before 1910, foreign private investment was visibly present in colonial Indonesia. The period between 1870 and 1895 had been one of transition in the sense that Dutch colonialism was intensified, spreading rapidly to territories that had not yet been brought under effective colonial rule (Lindblad, 1989: 9-16; 2008: 21-22).

After the Cultivation System was abolished, from 1870 onwards, Dutch policies towards private investment in colonial Indonesia changed. Companies from other countries were equally free to invest in the Netherlands Indies, but this was not always reflected in actual developments (Lindblad, in: van Zanden [ed.], 1996, 110-111; à Campo, 1995: 52).

This new era of colonial expansion spread from Java into the Outer Islands. The Aceh War of 1873 to 1914 marked the beginning. Through military expeditions, the Dutch conquered new territories in Sumatra, the Moluccas, Southeast Kalimantan, South and Central Sulawesi, Bali and Flores. This new interest in colonial Indonesia plays a pivotal part here. Even if not necessarily caused by it, economic expansion did certainly take place after effective colonial control had been established (Lindblad, 1989: 16). Initially, due to a liberal political stance, the colonial government did not have a largescale plan for economic expansion. As a result, private foreign investment was permitted to play a key role in the economic growth, especially in the Outer Islands (Locher-Scholten, 1994: 104; Dick, in: Lindblad [ed.], 1996, 36). However, the government stimulated private investment, creating favourable conditions in order to increase exports from colonial Indonesia (Lindblad, in: van Goor [ed.], 1986: 234). Eventually when safety could be guaranteed, the colonial government provided a favourable investment climate for private capital, in particular of Dutch origin. Familiarity with the legal system encouraged Dutch investment and facilitated the erection of business networks (Dick et al., 2002: 116). In order to show the volume of foreign private investment in colonial Indonesia, I first review the evolution of the number of companies. Their nationality, size and characteristics are described before I move on to the capital involved in investment.

\section{Number of Companies}

Even before the end of the Cultivation System, there were private companies active in the Netherlands Indies. Banks, insurance companies and transport firms had already emerged before the 1880s and between 1870 and 1900 the numbers of agricultural and mining companies rose considerably. Trading companies and manufacturing firms began to flourish after 1890 (à Campo, 1995: 49; à Campo, in: Lindblad (ed.), 1996: 75). In the period 1870-1913, some 3,800 individual firms were active in the Netherlands Indies with a peak in incorporations in 1910 when 326 new corporations were set up 
(Sluyterman, 2005: 40; à Campo, 1995: 46, 49-50).

The total increase of incorporated companies in the Netherlands, primarily active only in the Netherlands, showed a similar pattern. From 1890 onwards, this number increased rapidly. During 1890-1894, 150 firms were incorporated annually, and in 1912 this number rose to 1,269. However, different from in the Netherlands Indies, this number continued to grow in the Netherlands; in 1929 no less than 2,449 firms were incorporated (Renooij, 1951: 46).

The peak was reached much earlier in the Netherlands Indies. Data on numbers of individual companies stems from the database, now publicly available on a website (www.colonialbusinessindonesia.com). The information is based on the Handboek voor cultuur-en handelsondernemingen in Nederlandsch-Indië (Handbook for cultivation and trading companies in the Netherlands Indies). In this annual directory, all business companies incorporated under Dutch law are included. It is likely that most foreignowned firms are included here as well. Dutch legal status was also sought by local residents of Chinese descent and many of these companies are included as well. On the other hand, numbers of indigenous Indonesian enterprises are negligible since they usually operated under other legal conditions (Lindblad, in: van Zanden [ed.], 1996: 115; Dick et al., 2002: 116). Although some authors go even as far as to claim that the Chinese in Indonesia did not show much entrepreneurship, their presence in medium-sized enterprises was clearly visible in the Netherlands Indies, especially in trading. By the early 1920s, there were nearly 1,700 Chinese-owned firms employing more than five people. The number of European firms was 2,800, another 870 were owned by indigenous Indonesians (Booth, 1998: 310; Fernando \& Bulbeck, 1992: 254-259). This article does not discuss indigenous Indonesian and Chinese investment in detail, since the emphasis is on foreign investment and not domestic investment.

It is clear that agricultural companies remained the largest group in sheer numbers during the entire period, as shown in Table $1 .{ }^{1}$ This sector was followed by trade and commercial services. Although one could argue that industrial development became increasingly important in colonial Indonesia, which is here reflected in the category manufacturing, exports of primary agriculture products such as coffee, tobacco and especially sugar remained important. The reason why the total share of manufacturing was rather low was because manufacturing firms had to compete with importers from the Netherlands or other countries (Booth, 1998: 209; Dick et al., 2002: 158-159). The number of mining companies showed a gradual decline, but as will be made clear below, the average size of mining companies increased rapidly,

1) Source: based on the Excel file 'CBI Database ID', accessible at www. colonialbusinessindonesia.nl. 
as smaller companies were taken over by larger ones. It should be noted, however, that designations as 'agricultural' (cultuur) and 'trading' (handel) were part of the name of the companies and do not unambiguously reveal the type of activities undertaken. It was beneficial for firms to legally define a broad range of possible activities. Therefore it proved necessary to examine each case individually in the Handboek voor cultuur- en handelsondernemingen in Nederlandsch-Indië when compiling the database (Lindblad, 2014).

Table 1. Incorporated private business enterprises in the Netherlands Indies, 1910-1940.

\begin{tabular}{|c|c|c|c|c|c|c|c|}
\hline & 1910 & 1915 & 1920 & 1925 & 1930 & 1935 & 1940 \\
\hline Agriculture & $\begin{array}{c}836 \\
(40.6 \%)\end{array}$ & $\begin{array}{c}1,194 \\
(39.7 \%)\end{array}$ & $\begin{array}{c}1,292 \\
(34.6 \%)\end{array}$ & $\begin{array}{c}1,101 \\
(31.5 \%)\end{array}$ & $\begin{array}{c}1,019 \\
(35.7 \%)\end{array}$ & $\begin{array}{c}810 \\
(43 \%)\end{array}$ & $\begin{array}{c}835 \\
(38.7 \%)\end{array}$ \\
\hline Finance & $\begin{array}{c}82 \\
(4 \%)\end{array}$ & $\begin{array}{c}101 \\
(3.4 \%)\end{array}$ & $\begin{array}{c}122 \\
(3.3 \%)\end{array}$ & $\begin{array}{c}130 \\
(3.7 \%)\end{array}$ & $\begin{array}{c}122 \\
(4.3 \%)\end{array}$ & $\begin{array}{c}101 \\
(5.4 \%)\end{array}$ & $\begin{array}{l}107 \\
(5 \%)\end{array}$ \\
\hline Manufacturing & $\begin{array}{c}116 \\
(5.6 \%)\end{array}$ & $\begin{array}{c}214 \\
(7.1 \%)\end{array}$ & $\begin{array}{c}324 \\
(8.7 \%)\end{array}$ & $\begin{array}{c}352 \\
(10.1 \%)\end{array}$ & $\begin{array}{c}287 \\
(10.1 \%)\end{array}$ & $\begin{array}{c}174 \\
(9.2 \%)\end{array}$ & $\begin{array}{c}225 \\
(10.4 \%)\end{array}$ \\
\hline Mining & $\begin{array}{c}198 \\
(9.6 \%)\end{array}$ & $\begin{array}{c}199 \\
(6.6 \%)\end{array}$ & $\begin{array}{c}179 \\
(4.8 \%)\end{array}$ & $\begin{array}{c}107 \\
(3.1 \%)\end{array}$ & $\begin{array}{c}98 \\
(3.4 \%)\end{array}$ & $\begin{array}{c}67 \\
(3.6 \%)\end{array}$ & $\begin{array}{c}82 \\
(3.8 \%)\end{array}$ \\
\hline Other & $\begin{array}{c}264 \\
(12.8 \%)\end{array}$ & $\begin{array}{c}416 \\
(13.8 \%)\end{array}$ & $\begin{array}{c}531 \\
(14.2 \%)\end{array}$ & $\begin{array}{c}520 \\
(14.9 \%)\end{array}$ & $\begin{array}{c}441 \\
(15.5 \%)\end{array}$ & $\begin{array}{c}271 \\
(14.4 \%)\end{array}$ & $\begin{array}{c}314 \\
(14.5 \%)\end{array}$ \\
\hline Commercial services & $\begin{array}{c}216 \\
(12.8 \%)\end{array}$ & $\begin{array}{c}342 \\
(11.4 \%)\end{array}$ & $\begin{array}{c}543 \\
(14.5 \%)\end{array}$ & $\begin{array}{c}561 \\
(16 \%)\end{array}$ & $\begin{array}{c}360 \\
(12.6 \%)\end{array}$ & $\begin{array}{c}190 \\
(10.1 \%)\end{array}$ & $\begin{array}{c}251 \\
(11.6 \%)\end{array}$ \\
\hline Trading & $\begin{array}{c}348 \\
(16.9 \%)\end{array}$ & $\begin{array}{c}543 \\
(18.1 \%)\end{array}$ & $\begin{array}{c}745 \\
(19.9 \%)\end{array}$ & $\begin{array}{c}726 \\
(20.8 \%)\end{array}$ & $\begin{array}{c}527 \\
(18.5 \%)\end{array}$ & $\begin{array}{c}271 \\
(14.4 \%)\end{array}$ & $\begin{array}{c}342 \\
(15.9 \%)\end{array}$ \\
\hline Total $^{*}$ & $\begin{array}{c}2,060 \\
(100 \%)\end{array}$ & $\begin{array}{c}3,009 \\
(100 \%)\end{array}$ & $\begin{array}{c}3,736 \\
(100 \%)\end{array}$ & $\begin{array}{c}3,497 \\
(100 \%)\end{array}$ & $\begin{array}{c}2,854 \\
(100 \%)\end{array}$ & $\begin{array}{c}1,884 \\
(100 \%)\end{array}$ & $\begin{array}{c}2,156 \\
(100 \%)\end{array}$ \\
\hline
\end{tabular}

Source: See note 2.

*Includes Chinese and indigenous Indonesian incorporated firms with headquarters in the Netherlands Indies.

The large number of incorporated business firms in 1920 and 1925 reflects the widespread optimism of the international economy after the First World War. However, this upsurge was followed by a contraction and by 1930 the number had declined by one-quarter and continued dropping until 1935. In 1940, the total number of foreign companies was only slightly higher than in 1910. The reason why the number of firms kept falling during the economic boom of the 1920s is twofold. In the first place, various enterprises were set up during a period of exuberant optimism which lasted until the 
early 1920s, but many did not become profitable within a few years. Secondly, many successful companies took over smaller ones, resulting in a smaller total number (Lindblad, 2014: 5-6). ${ }^{2}$

Numbers by nationality remained relatively constant over time (Table 2). ${ }^{3}$ The share of companies with headquarters in the Netherlands barely changed between 1910 and 1940 and was around 26\% in either year. Leaving out domestic investment by Chinese and indigenous Indonesians, this share would be 32\% and 34\% in 1910 and 1940, respectively. The share of Dutch companies with headquarters in the Netherlands Indies even declined in the long run. At first, in 1910, it was 52\% of all firms, by 1940 this proportion had dropped to $47 \%$. Without domestic investment, this proportion amounted to $64 \%$ in 1910 and $60 \%$ in 1940.

According to à Campo Dutch corporations were liquidated more often than firms from third countries and he argues that Netherlands-based corporations became less important in the Netherlands Indies (à Campo, 1995: 50). This might be true for the late nineteenth and early twentieth century and the percentage of Dutch-based companies did decline until 1925 but after this year their share increased again until 1940 when it was nearly the same as in 1910. On the other hand, the share of Netherlands Indies companies declined gradually from 1910 onwards. One could better argue that Netherlands-based corporations did not become less important, but rather more important, especially after the economic depression of the 1930s. Another trend was the increasing number of Netherlands Indies companies with headquarters in the Outer Islands and the rising share of companies from third countries, especially from the United Kingdom (à Campo, 1995: 50). Their combined share was around 3\% in 1910 and around 6\% of the total number in 1940. The share of foreign non-Dutch companies active in the Netherlands Indies was probably higher than these numbers show. The nationality of firms is not given in the source but it is known that many companies from third countries operated through a subsidiary firm in the Netherlands Indies.

Non-Dutch foreign investors could also decide to cooperate with Dutch investors. Apart from mutual economic interests, they could also try to get a foothold in the Netherlands Indies for political reasons. Even though the Dutch government promoted an open door policy, in reality foreign companies did face opposition. This especially applied to German and Japanese investors. Although there was not much open discrimination, Dutch

2) This document is accessible under'Publications' at www.colonialbusinessindonesia. nl.

3) Based on designations of nationality by Thomas Lindblad, using the original Excel file 'CBI Database ID', which is accessible at www.colonialbusinessindonesia.nl. The version with nationalities attached is available on request. See also J. Thomas Lindblad, 'Foreign capital and colonial development in Indonesia: A synthesis' above, Table 2. 
enterprises were advantaged by their familiarity with Dutch procedures, language, institutions and jurisdiction (à Campo, 1995: 52; à Campo, in: Lindblad [ed.], 1996, 77; Dick et al., 2002: 116).

Table 2. Numbers of incorporated private business enterprises in the Netherlands Indies by nationality, 1910-1940.

\begin{tabular}{|c|c|c|c|c|c|c|c|}
\hline & 1910 & 1915 & 1920 & 1925 & 1930 & 1935 & 1940 \\
\hline Chinese* & $\begin{array}{c}358 \\
(17.4 \%)\end{array}$ & $\begin{array}{c}607 \\
(20.2 \%)\end{array}$ & $\begin{array}{c}834 \\
(22.3 \%)\end{array}$ & $\begin{array}{c}838 \\
(24 \%)\end{array}$ & $\begin{array}{c}690 \\
(24.2 \%)\end{array}$ & $\begin{array}{c}310 \\
(16.5 \%)\end{array}$ & $\begin{array}{c}434 \\
(20.1 \%)\end{array}$ \\
\hline $\begin{array}{l}\text { Indigenous } \\
\text { Indonesian }\end{array}$ & $\begin{array}{c}25 \\
(1.2 \%)\end{array}$ & $\begin{array}{c}60 \\
(2 \%)\end{array}$ & $\begin{array}{c}74 \\
(2 \%)\end{array}$ & $\begin{array}{c}62 \\
(1.8 \%)\end{array}$ & $\begin{array}{c}43 \\
(1.5 \%)\end{array}$ & $\begin{array}{c}11 \\
(0.6 \%)\end{array}$ & $\begin{array}{c}20 \\
(0.9 \%)\end{array}$ \\
\hline $\begin{array}{l}\text { Dutch with } \\
\text { headquarters in } \\
\text { the Netherlands } \\
\text { Indies }\end{array}$ & $\begin{array}{c}1,077 \\
(52.3 \%)\end{array}$ & $\begin{array}{c}1,507 \\
(50.1 \%)\end{array}$ & $\begin{array}{l}1,943 \\
(52 \%)\end{array}$ & $\begin{array}{c}1,745 \\
(49.9 \%)\end{array}$ & $\begin{array}{c}1,349 \\
(47.3 \%)\end{array}$ & $\begin{array}{c}863 \\
(45.8 \%)\end{array}$ & $\begin{array}{l}1,014 \\
(47 \%)\end{array}$ \\
\hline $\begin{array}{l}\text { Dutch with } \\
\text { headquarters in } \\
\text { the Netherlands }\end{array}$ & $\begin{array}{c}543 \\
(26.4 \%)\end{array}$ & $\begin{array}{c}669 \\
(22.2 \%)\end{array}$ & $\begin{array}{c}713 \\
(19.1 \%)\end{array}$ & $\begin{array}{c}686 \\
(19.6 \%)\end{array}$ & $\begin{array}{c}649 \\
(22.7 \%)\end{array}$ & $\begin{array}{c}593 \\
(31.5 \%)\end{array}$ & $\begin{array}{c}579 \\
(26.9 \%)\end{array}$ \\
\hline United Kingdom** & $\begin{array}{c}48 \\
(2.3 \%)\end{array}$ & $\begin{array}{c}137 \\
(4.6 \%)\end{array}$ & $\begin{array}{c}135 \\
(3.6 \%)\end{array}$ & $\begin{array}{c}131 \\
(3.7 \%)\end{array}$ & $\begin{array}{c}102 \\
(3.6 \%)\end{array}$ & $\begin{array}{c}89 \\
(4.7 \%)\end{array}$ & $\begin{array}{c}87 \\
(4 \%)\end{array}$ \\
\hline Other foreign ${ }^{\star * *}$ & $\begin{array}{c}9 \\
(0.4 \%)\end{array}$ & $\begin{array}{c}29 \\
(1 \%)\end{array}$ & $\begin{array}{c}37 \\
(1 \%)\end{array}$ & $\begin{array}{c}35 \\
(1 \%)\end{array}$ & $\begin{array}{c}21 \\
(0.7 \%)\end{array}$ & $\begin{array}{c}18 \\
(1 \%)\end{array}$ & $\begin{array}{c}22 \\
(1 \%)\end{array}$ \\
\hline Total foreign ${ }^{\star \star \star \star}$ & 1,677 & 2,342 & 2,828 & 2,597 & 2,121 & 1,563 & 1,702 \\
\hline Total & 2,060 & 3,009 & 3,736 & 3,497 & 2,854 & 1,884 & 2,156 \\
\hline
\end{tabular}

Source: See note 4.

* Refers to Chinese companies with headquarters in the Netherlands Indies.

** Including a small number of companies from the United States.

*** Including firms incorporated in Austria, Belgium, China, Denmark, France, Italy, Japan, Malaysia, Norway, Sweden, and Switzerland.

**** Excludes Chinese and indigenous Indonesian incorporated companies with headquarters in the Netherlands Indies. Investment by residents of the Netherlands Indies of Chinese descent was for all intents and purposes domestic investment although the investors by Chinese law possessed Chinese citizenship.

A characteristic of most of the Dutch investors was that they were so-called free-standing companies. Wilkins and Sluyterman use this term to describe a firm set up in one country with the purpose of doing business in another country. These free-standing companies differ from multinationals starting in one country and then expanding to other countries. The Netherlands Indies was often seen as part of the Dutch network. Initiatives for setting up companies in the Netherlands Indies often came from people who were already living there and who saw opportunities for doing business (Sluyterman, 2005: 41; Wilkins, 1988: 261). Managers in the Netherlands tried to stay up-to-date with the business activities in the Netherlands Indies using the telegraph to exchange information with the overseas subsidiary (Sluyterman, 2005: 39-42; Lindblad, 1989: 13; Lindblad, in: van Goor [ed.], 1986, 242; van der Eng, 1998: 17; van Lynden, 1945: 6, 116-117). In reality, local managers could rather autonomously decide how to operate their business, since intervention was difficult. They knew more about the local production and developments in the colony. Yet, they still depended on Dutch 
capital and the relationship was tricky. It was not always easy to convince the board in the Netherlands that certain investments were necessary. Only gradually did this relationship improve as knowledge was accumulated about how to do business in the Netherlands Indies (Sluyterman, 2005: 45-46).

À Campo warns that the growing number of incorporated companies until the 1920s alone is not a good indicator for the economic development of the Netherlands Indies. Public investment and non-incorporated firms are left out. In addition the incorporation of a company does not automatically imply that it was a new company. A company could be taken over, merge with another company or simply be re-established. This cannot be deduced from the database or from the original source (à Campo, 1995: 53-54; à Campo, in: Lindblad [ed.], 1996: 78).

Table 3. Periods of incorporation of private business enterprises in the Netherlands Indies, listed in 1910-1940.

\begin{tabular}{cccccccc}
\hline & 1910 & 1915 & 1920 & 1925 & 1930 & 1935 & 1940 \\
\hline \multirow{2}{*}{$<1870$} & 27 & 27 & 26 & 29 & 28 & 29 & 33 \\
& $(1.3 \%)$ & $(0.9 \%)$ & $(0.7 \%)$ & $(0.8 \%)$ & $(1 \%)$ & $(1.6 \%)$ & $(1.5 \%)$ \\
$1871-1890$ & $171(8.3 \%)$ & 148 & 139 & 112 & 103 & 91 & 95 \\
& & $(5 \%)$ & $(3.8 \%)$ & $(3.3 \%)$ & $(3.7 \%)$ & $(4.9 \%)$ & $(4.5 \%)$ \\
$1891-1900$ & 581 & 469 & 399 & 287 & 224 & 183 & 181 \\
& $(28.4 \%)$ & $(15.8 \%)$ & $(10.9 \%)$ & $(8.4 \%)$ & $(8 \%)$ & $(9.8 \%)$ & $(8.5 \%)$ \\
$1901-1910$ & 1,270 & 1,450 & 1,257 & 910 & 639 & 368 & 358 \\
& $(62 \%)$ & $(48.8 \%)$ & $(34.3 \%)$ & $(26.6 \%)$ & $(22.8 \%)$ & $(19.8 \%)$ & $(16.9 \%)$ \\
$1911-1920$ & & 878 & 1,839 & 1,575 & 987 & 363 & 350 \\
& & $(29.5 \%)$ & $(50.2 \%)$ & $(46.1 \%)$ & $(35.2 \%)$ & $(19.5 \%)$ & $(16.6 \%)$ \\
$1921-1930$ & & & & 502 & 820 & 536 & 433 \\
& & & & $(14.7 \%)$ & $(29.3 \%)$ & $(28.8 \%)$ & $(20.5 \%)$ \\
$1931-1940$ & & & & & & 293 & 664 \\
& & & & & & $(15.7 \%)$ & $(31.4 \%)$ \\
\hline Total $^{*}$ & 2,049 & 2,972 & 3,660 & 3,415 & 2,801 & 1,863 & 2,114 \\
\hline
\end{tabular}

Source: See note 2.

* Includes Chinese and indigenous Indonesian incorporated firms with headquarters in the Netherlands Indies. Date of incorporation is not known for every company.

Another characteristic of companies active in the Netherlands Indies is that they were relatively young. In Table 3 the firms are divided into seven different time periods based on the year of incorporation of the companies. For the years 1910, 1920 and 1940, companies founded in the immediately preceding ten years formed the largest category. In 1940, the share of companies founded between 1931 and 1940 was higher than that of companies originating from the years 1920 to 1930. Apparently, the onslaught of the depression did not have a large effect on the very incorporation of new companies. It must be noted, however, that the number of companies had already declined during the 1920s and only slightly increased in the second half of the 1930s, after the depression had subsided. 
Of all categories the first one, containing firms from before 1870, actually came to occupy a higher share in the long run. This was possible if companies started their operations in the Netherlands and only later became active in the Netherlands Indies. For the other categories their share in the total dropped rapidly as time passed by. Of the 171 companies founded between 1871 and 1890 and active in the colony in 1910 only 95, slightly more than half, were still active in 1940. For the later period these figures were even less impressive. In 1910, for instance, there were 581 companies founded between 1891 and 1900 of which 181 (31\%) were left in 1940, and of 1,270 firms founded between 1901 and 1910358 (28\%) were remaining in 1940 .

Of all companies incorporated before 1870 financial enterprises accounted for the largest share, about two thirds of all firms incorporated before 1870. Only one company in agriculture, the Deli Maatschappij (Deli Company), one in mining, the Billiton Maatschappij (Billiton Company) and one in trading, Nederlandsche Handel-Maatschappij (Netherlands Trading Association, NHM) dated from before $1870 .{ }^{4}$ In the agricultural sector most companies were incorporated between 1901 and 1910, followed by the next decade, 1911-1920. In mining 1901-1910 was the most popular period too, yet was followed by the earlier decade 1891-1900. Even in finance, 1911-1920 proved to be the period when most corporations were founded. In 1920, firms from the preceding decade amounted to 454 companies in trading, or $62 \%$ of all companies for which the year of incorporation is known. A final important observation with regard to the chronology of incorporation is that virtually all companies founded before 1870 were either Dutch or had headquarters in the Netherlands Indies. ${ }^{5}$

\section{Volume of Investment}

The following section discusses the expansion of foreign direct investment (FDI) as opposed to portfolio investment. FDI is defined as investment involving a long-term relationship in productive capital like factories or subsidiaries, with a lasting interest in a different economy than that of the investor. Unlike portfolio investment the direct investor wishes to be directly involved with the management of the company in the host country. In practice this means that the foreign investor played a major role in founding and operating a company in the Netherlands Indies and usually did not invest in local non-foreign companies (Lindblad, 1998: 1; van Lynden, 1945: 6-7).

4) Internationale Crediet- en Handels-Vereeniging 'Rotterdam' (International Credit and Trading Association 'Rotterdam'), Internatio, and other trading companies are ranked under financial enterprises in the database.

5) Source: based on the Excel file 'CBI Database ID', accessible at www. colonialbusinessindonesia.nl. 
Here foreign direct investment is defined as private investment originating outside the Netherlands Indies. The Netherlands Indies is perceived as akin to a foreign destination. It was constitutionally separated from the Netherlands and had an independent monetary policy and its own currency and balance of trade (van Lynden, 1945: 6, 116-117).

In the last quarter of the nineteenth century, capital for this kind of investment was mostly provided by the founder himself. Initially the interest in tropical adventures was limited at the capital market. Self-made businessmen formed networks with banks and trading houses (van der Eng, 1998: 16; Taselaar, 1998: 35; van Zanden \& Marks, 2012: 82). For ventures founded between 1890 and 1905, the founders themselves brought in an average equity of 25 to $35 \%$. This percentage varied widely and was significant in the agricultural and mining industry where early prospecting was indispensable. The amount of founders' equity varied and was significantly higher for companies with headquarters in the Netherlands than in the Netherlands Indies. À Campo estimates that the average was around $f 500,000$ in 1890 to $f 800,000$ in 1913 (à Campo, 1995: 60; à Campo, in: Lindblad [ed.], 1996: 80, 84).

Banks also provided investment capital in the late nineteenth century. Along with De Javasche Bank (Java Bank, DJB), NHM, NederlandschIndische Escompto Maatschappij (Netherlands indies Escompto Company, NIEM), Nederlandsch-Indische Landbouw Maatschappij (Netherlands Indies Agricultural Company, NILM), the Rotterdamsche Bank, the NederlandschIndische Handelsbank (Netherlands Indies Trading Bank, NIHB), Internatio, HVA and the Koloniale Bank (Colonial Bank) made investments for the export production possible (Helfferich, 1914: 32-33; Sluyterman, 2005: 42).

During the sugar crisis of 1884 prices of primary export products dropped which caused serious trouble for companies that had borrowed money (van der Eng, 1998: 17-18; Sluyterman, 2005: 39-40; Lindblad, 1989: 13; Lindblad, in: van Goor [ed.], 1986: 242).

The result of the crisis was that banks became more reluctant to provide capital to new companies. In the early twentieth century, the capital market in colonial Indonesia was insignificant. It was more common to reinvest profits in the Netherlands Indies than in the Netherlands due to the higher risks of operating business in the colony and fluctuating prices. It is estimated that between 1925 and 1938 around one-quarter to one-third of profits were ploughed back and reinvested in companies in the Netherlands Indies. Therefore, it is likely that between two third and 75\% of profits were paid out as dividends (Taselaar, 1998: 35; Korthals Altes, 2004: 140-143; Helfferich, 1914: 180; Bosch, 1948: 77-78; Lindblad, 1998: 7; Creutzberg, 1977: 28).

Another consequence of the crisis of 1884 was that more companies converted into joint stock limited liability companies (naamloze vennootschap) 
(Taselaar, 1998: 35). Initially, the purpose of founding joint-stock companies was to acquire larger amounts of equity which was otherwise not readily accessible, especially with private limited liability companies (besloten vennootschap) (Renooij, 1951: 47). Dutch companies only active in the colony were more often joint-stock companies than companies operating in the Netherlands (Renooij, 1951: 119). Raising money in the Dutch stock market was often no option for smaller companies, since stock market listings required a minimum of $f 500,000$ subscribed equity (van der Eng, 1998: 16). Overall, Dutch companies active in the Netherlands Indies became more professional and better organized and when smaller companies were bought out, the ownership of these assets usually changed which led to a relatively small number of companies in the Netherlands with many assets.

Indigenous Indonesians, and to a lesser extent, Chinese were disadvantaged compared with European entrepreneurs. The number of lending institutions in the colony was low and many entrepreneurs relied on capital of the Dutch-owned banks in the Netherlands Indies. They all required some collateral, which made it nearly impossible for indigenous Indonesians to get credit, although the Chinese were more successful and sometimes managed to acquire funding from other foreign banks. Only from $1912 \mathrm{did}$ offices of the Volkscredietbank (People's Credit Bank) emerge destined to stimulate indigenous business activities. Results were disappointing, especially compared with foreign investment (Lindblad, 2008: 31).

Even though it was much easier for Dutch people to invest in the Netherlands Indies, initially the amounts of capital entering colonial Indonesia were relatively small compared with investment done by the Dutch in other foreign countries. A substantial part of Dutch overseas investment was portfolio investment. Even in 1914, combined portfolio investment in Russia and the United States was far higher valued than all Dutch-owned assets in the Netherlands Indies, around $f 3$ billion against slightly more than $f 1$ billion (van der Eng, 1998: 19-20; van Soest, 1938: 38-62).

More popular among Dutch investors in the Netherlands Indies was the purchase of Indonesian public bonds, which were guaranteed by the Dutch government. The public debt of colonial Indonesia increased substantially during the first quarter of the twentieth century in order to finance infrastructure and finance expenditures. Although the Netherlands Indies enjoyed a trade surplus, largely based on rising export volumes. The colonial government had to borrow money to pay off its debt. Companies could also issue bonds, but this was rather uncommon. On average this accounted for not much more than $10 \%$ of total equity. Overall, the share of investment in the Netherlands Indies in total Dutch foreign investment rose from around $20 \%$ in 1900 to $46 \%$ in 1938 . This was not entirely caused by new capital flowing to the Netherlands Indies. Reinvesting profits increased the 
value of various companies significantly and plantations and companies taken over in the Netherlands Indies from less fortunate owners by more profitable companies also led to an accumulation of wealth (van der Eng, 1998: 309-310; à Campo, 1995: 55, 58-59; à Campo, in: Lindblad [ed.], 1996: 83-84).

Demand for capital in the Netherlands Indies rose rapidly in the early twentieth century. A detailed calculation of Dutch investment in colonial Indonesia shows that of all capital issued in the Netherlands in 1904, 15\% went to the Netherlands Indies even excluding the Koninklijke Maatschappij tot Exploitatie van Petroleumbronnen in Nederlandsch-Indië (Royal Dutch). This proportion increased in the following year, in 1909 amounting to 31\% (around 40\% including the Royal Dutch). Although the share then dropped, in 1914 it increased again to 36\%. In 1907, 1909 and 1913 the share of the joint subsidiaries of Royal Dutch and British-owned Shell corresponded to $18 \%, 8.4 \%$ and $14.6 \%$ of total Dutch capital issued. For the period 1904-1914 issued capital for companies in the Netherlands Indies was $24.8 \%$ of total issued capital in the Netherlands. Including equity of the Royal Dutch Shell, this figure would be closer to 30\% (de Roos \& Wieringa, 1953: 56-57).

Calculations of the amount of capital invested by the Netherlands in other countries differ. Derksen made an estimation for 1913 of $f 3,020$ million in constant prices, excluding investment in the Netherlands Indies. For 1934 he stated an amount of $f 1,013$ million in constant prices, but even with the deflation during the economic depression of the 1930s it is unlikely that this difference would be that large. A calculation by van Soest shows that in 1936 a total of $f 2,247$ million was invested abroad, and another $f 2,265$ million was invested in the Netherlands Indies at that time, which confirms that in the second half of the 1930s around half of total Dutch foreign investment took place in the Netherlands Indies. The Central Bureau of Statistics shows similar results, in 1938, an estimated amount of $f 2.1$ billion was invested abroad, excluding the Netherlands Indies. It should be noted that van Soest also includes foreign government bonds. According to his calculations, stocks in the Netherlands Indies were valued at $f 1,183$ million in 1936 and bonds at $f 1,082$ million. If we use the stock market figures of 1929, when shares were valued higher than in 1936, different numbers emerge. The total value of shares in the Netherlands Indies would then be $f 2,740$ million with bonds valued at $f 935$ million; this brings the combined total to $f 3,675$ million (Renooij, 1951: 164-165; van Soest, 1938: 44).

A calculation by Renooij shows the total value of issued bonds and stocks in the Netherlands between 1910 and 1939 to be worth $f 4,988$ million in current prices. Domestic investment was $f 3,379$ million and investment overseas was $f 1,609$ million, of which $f 604$ million at Royal Dutch Shell alone (Renooij, 1951: 116). In certain years, especially when Royal Dutch Shell issued equity, domestic investment in the Netherlands would be less than half 
of total investment. Therefore, it is valid to say that around half of total Dutch foreign investment was done in the Netherlands Indies, or in companies that were active in the colony. Since total foreign investment was around half of total Dutch investment, around one-quarter of all Dutch investment was done in the Netherlands Indies. In 1938 this generated around 8\% of Dutch national income, not counting multiplier effects (Derksen \& Tinbergen, 1941: 8-9; van Zanden \& Marks, 2012: 129). Seen from an Indonesian perspective, total foreign investment (Dutch investment including investment from other third countries) was around $28 \%$ of gross domestic product (GDP) in 1913, $30 \%$ in 1924, 66\% in 1930 and 69\% in 1940. If we include investment by the colonial government these numbers rise to $35 \%, 46 \%, 82 \%$ and $87 \%$, respectively (Booth, 1998: 255). The annual flow of investment as a share of national Indonesian income was 7.2\% in 1921, 5.3\% in 1922 and 1923, 5\% between 1924 and 1930, 2.1\% between 1931 and 1936 and 3.2\% between 1937 and 1939 (Creutzberg, 1977: 22).

Table 4. Total equity of incorporated firms by nationality in the Netherlands Indies, in million guilders, at current prices, 1910-1940.

\begin{tabular}{cccccccc}
\hline & 1910 & 1915 & 1920 & 1925 & 1930 & 1935 & 1940 \\
\hline $\begin{array}{c}\text { Dutch with } \\
\text { headquarters in the } \\
\text { Netherlands }\end{array}$ & 844 & 1,323 & 1,778 & 2,559 & 3,043 & 3,092 & 3,075 \\
$\begin{array}{c}\text { Dutch with } \\
\text { headquarters in the }\end{array}$ & 299 & 450 & 638 & 799 & 760 & 629 & 625 \\
Netherlands Indies & $(0.28)$ & $(0.30)$ & $(0.33)$ & $(0.46)$ & $(0.56)$ & $(0.73)$ & $(0.62)$ \\
UK & 54 & 234 & 244 & 297 & 331 & 285 & 344 \\
& $(1.13)$ & $(1.70)$ & $(1.81)$ & $(2.27)$ & $(3.25)$ & $(3.20)$ & $(3.95)$ \\
Other & 6 & 42 & 45 & 99 & 86 & 300 & 599 \\
Foreign & $(0.67)$ & $(2.00)$ & $(1.61)$ & $(3.41)$ & $(4.10)$ & $(17.65)$ & $(29.95)$ \\
& 60 & 123 & 142 & 245 & 209 & 134 & 312 \\
Chinese & $(0.17)$ & $(0.20)$ & $(0.17)$ & $(0.29)$ & $(0.30)$ & $(0.43)$ & $(0.72)$ \\
Indigenous & 3 & 5 & 7 & 12 & 8 & 4 & 4 \\
Indonesian & $(0.12)$ & $(0.08)$ & $(0.09)$ & $(0.19)$ & $(0.19)$ & $(0.36)$ & $(0.20)$ \\
Total & 1,266 & 2,177 & 2,854 & 4,011 & 4,437 & 4,444 & 4,959 \\
& $(0.61)$ & $(0.72)$ & $(0.76)$ & $(1.15)$ & $(1.55)$ & $(2.36)$ & $(2.30)$ \\
Total foreign* & 1,203 & 2,049 & 2,705 & 3,754 & 4,220 & 4,306 & 4,643 \\
& $(0.75)$ & $(0.88)$ & $(0.96)$ & $(1.45)$ & $(1.99)$ & $(2.76)$ & $(2.73)$ \\
\hline
\end{tabular}

Source: See note 12. Average equity per firm within brackets.

* Excludes Chinese and indigenous Indonesian incorporated firms with headquarters in the Netherlands Indies.

Table 4 shows the total equity of incorporated firms in the Netherlands Indies. Usually equity is given for paid-up capital, which means the equity had already been issued. Sometimes nominal equity was stated, which means that not all equity was issued in the year cited in the directory, but would be issued within a short period of time. Equity is given here in current prices, which means that no adjustment was done for inflation. Therefore, it is 
not surprising that both total and average equity per firm increased in the long run. Even in 1940, the share of foreign companies with equity of less than $f 500,000$ was as high as $53.7 \%$. Although this percentage had declined from $75.2 \%$ in 1910 , there were apparently many small firms operating in the Netherlands Indies on the eve of the Pacific War. Amongst the higher categories, companies with equity of at least $f 10$ million showed the strongest increase from 13 to 68 companies. There was a dichotomy of a large group of small companies and a small group of large companies in the colony. ${ }^{6}$

Expressed at current prices, equity of Dutch companies in the colony continued to increase after 1925, whereas the peak for the Netherlands indies companies was already reached in that year. Interesting differences emerge if we adjust for inflation. Prices increased rapidly in the Netherlands Indies after the First World War but dropped during the 1920s and continued to do so until the mid-1930s. In the second half of the 1930s prices even were still only around one half of the prices of 1920 (van Leeuwen, 2007: 240-241). The deflation of the 1930s was far more extreme in the Netherlands Indies than in the Netherlands. In the Netherlands, price levels at the end of the 1930s were only slightly higher than during 1910, whereas in the Netherlands Indies, prices of the late 1930s were significantly lower than in $1910 .^{7}$

Therefore, if we apply a correction for inflation, the results are staggering (Table 5). A total amount of foreign investment measuring more than $f 6$ billion in 1935 is highly unlikely, especially if amounting only slightly more than half five years earlier, when the economic depression of the 1930s hit the economy of the Netherlands Indies. Total equity of Dutch companies with headquarters in the Netherlands Indies increased until 1935 and was only marginally lower in 1940. Investment from third countries, except Great Britain, in the Netherlands Indies increased significantly, in 1940 nearly touching the same level as that of Netherlands Indies companies. In 1936 the Dutch guilder devaluated with 20\% when it abandoned the gold standard (Don \& Verbruggen, 2006: 21). Therefore it is reasonable to state that the real value of Dutch companies in 1940 was lower than is shown in Table 5.

Figures about investment after the Pacific War until the nationalization of foreign companies in Indonesia, in the late 1950s, are very scarce. However, one calculation by Creutzberg shows that in current prices total Dutch investment in Indonesia was $f 892$ million between 1945 and 1957

6) Source: based on designations of nationality by Thomas Lindblad, using the original Excel file 'CBI Database ID', which is accessible at www.colonialbusinessindonesia. nl. The version with nationalities attached is available on request. See also J. Thomas Lindblad, 'Foreign capital and colonial development in Indonesia: A synthesis' above, Table 1. There is a difference in the total for 1940, which here has not been adjusted for the lower value of the guilder after the devaluation in 1936.

7) 'Consumentenprijzen; prijsindex $1900=100$ '. Source: Centraal Bureau voor de Statistiek (Central Bureau of Statistics), at www.statline.cbs.nl. 
(Creutzberg, 1977: 21). Although this amount appears impressive, one must not forget that inflation in both Indonesia and the Netherlands was high in this period. For the Netherlands, this price index more than doubled between 1940 and $1955^{8}$ and figures for Indonesia increased even more rapidly (Arndt, 1966: 59).

Table 5. Total equity of incorporated firms in the Netherlands Indies in million guilders in prices of 1913, by nationality, 1910-1940.

\begin{tabular}{cccccccc}
\hline & 1910 & 1915 & 1920 & 1925 & 1930 & 1935 & 1940 \\
\hline $\begin{array}{c}\text { Dutch with } \\
\text { headquarters in the } \\
\text { Netherlands }\end{array}$ & 979 & 1,398 & 779 & 1,954 & 2,532 & 4,415 & 3,971 \\
$\begin{array}{c}\text { Dutch with } \\
\text { headquarters in the }\end{array}$ & 334 & $(2.09)$ & $(1.09)$ & $(2.85)$ & $(3.90)$ & $(7.44)$ & $(6.86)$ \\
Netherlands Indies & $(0.32)$ & $(0.32)$ & $(0.14)$ & $(0.35)$ & $(0.47)$ & $(1.04)$ & $(0.80)$ \\
& & & & & & & \\
United Kingdom & 63 & 247 & 107 & 227 & 275 & 407 & 444 \\
& $(1.31)$ & $(1.80)$ & $(0.79)$ & $(1.73)$ & $(2.70)$ & $(4.57)$ & $(5.10)$ \\
Other foreign & 7 & 44 & 20 & 76 & 72 & 428 & 774 \\
& $(0.78)$ & $(2.11)$ & $(0.71)$ & $(2.60)$ & $(3.41)$ & $(25.20)$ & $(38.68)$ \\
Chinese & 70 & 130 & 62 & 187 & 174 & 191 & 403 \\
& $(0.20)$ & $(0.21)$ & $(0.07)$ & $(0.22)$ & $(0.25)$ & $(0.61)$ & $(0.93)$ \\
Indigenous & 3 & 5 & 3 & 9 & 7 & 6 & 5 \\
Indonesian & $(0.14)$ & $(0.08)$ & $(0.04)$ & $(0.15)$ & $(0.16)$ & $(0.51)$ & $(0.26)$ \\
Total & 1,469 & 2,300 & 1,250 & 2,869 & 3,691 & 6,346 & 6,404 \\
& $(0.71)$ & $(0.76)$ & $(0.33)$ & $(0.88)$ & $(1.29)$ & $(3.37)$ & $(2.97)$ \\
Total foreign* & 1,396 & 2,165 & 1,185 & 2,866 & 3,511 & 6,149 & 5,996 \\
& $(0.87)$ & $(0.93)$ & $(0.42)$ & $(1.11)$ & $(1.66)$ & $(3.94)$ & $(3.52)$ \\
\hline
\end{tabular}

Source: See note 4.

* Excludes Chinese and indigenous Indonesian incorporated firms with headquarters in the Netherlands Indies.

Table 6. Total equity of foreign incorporated firms by nationality in the Netherlands Indies as a share of total foreign investment, 1910-1940.

\begin{tabular}{cccccccc}
\hline & 1910 & 1915 & 1920 & 1925 & 1930 & 1935 & 1940 \\
\hline $\begin{array}{c}\text { Dutch with } \\
\text { headquarters in the } \\
\text { Netherlands }\end{array}$ & $70.2 \%$ & $64.6 \%$ & $65.7 \%$ & $68.2 \%$ & $72.1 \%$ & $71.8 \%$ & $66.2 \%$ \\
$\begin{array}{c}\text { Dutch with } \\
\text { headquarters in the }\end{array}$ & $24.9 \%$ & $22 \%$ & $23.6 \%$ & $21.3 \%$ & $18 \%$ & $14.6 \%$ & $13.4 \%$ \\
$\begin{array}{c}\text { Netherlands Indies } \\
\text { United Kingdom }\end{array}$ & $4.5 \%$ & $11.4 \%$ & $9 \%$ & $7.9 \%$ & $7.8 \%$ & $6.6 \%$ & $7.4 \%$ \\
$\quad$ Other & $0.5 \%$ & $2 \%$ & $1.7 \%$ & $2.6 \%$ & $2 \%$ & $7 \%$ & $12.9 \%$ \\
$\quad$ Total foreign* & $100 \%$ & $100 \%$ & $100 \%$ & $100 \%$ & $100 \%$ & $100 \%$ & $100 \%$ \\
\hline
\end{tabular}

Source: See note 4.

* Excludes Chinese and indigenous Indonesian incorporated firms with headquarters in the Netherlands Indies.

8) 'Consumentenprijzen; prijsindex $1900=100$ '. Source: Centraal Bureau voor de Statistiek (Central Bureau of Statistics), at www.statline.cbs.nl. 
Table 7. Total equity of incorporated firms in the Netherlands Indies by industry in million guilders, 1910-1940, at prices of 1913.

\begin{tabular}{|c|c|c|c|c|c|c|c|}
\hline & 1910 & 1915 & 1920 & 1925 & 1930 & 1935 & 1940 \\
\hline Agriculture & $\begin{array}{c}498 \\
(0.63) \\
35.7 \%\end{array}$ & $\begin{array}{c}892 \\
(0.80) \\
41.2 \%\end{array}$ & $\begin{array}{c}427 \\
(0.36) \\
36 \%\end{array}$ & $\begin{array}{c}984 \\
(0.96) \\
34.4 \%\end{array}$ & $\begin{array}{l}1,295 \\
(1.37) \\
36.9 \%\end{array}$ & $\begin{array}{l}2,126 \\
(2.77) \\
34.6 \%\end{array}$ & $\begin{array}{l}1,876 \\
(2.40) \\
31.3 \%\end{array}$ \\
\hline Finance & $\begin{array}{c}143 \\
(1.86) \\
10.2 \%\end{array}$ & $\begin{array}{c}245 \\
(2.76) \\
11.3 \%\end{array}$ & $\begin{array}{c}131 \\
(1.26) \\
11.1 \%\end{array}$ & $\begin{array}{c}311 \\
(2.91) \\
10.9 \%\end{array}$ & $\begin{array}{c}348 \\
(3.44) \\
9.9 \%\end{array}$ & $\begin{array}{c}907 \\
(9.95) \\
14.8 \%\end{array}$ & $\begin{array}{c}1,342 \\
(13.83) \\
22.4 \%\end{array}$ \\
\hline Manufacturing & $\begin{array}{c}38 \\
(0.39) \\
2.7 \%\end{array}$ & $\begin{array}{c}94 \\
(0.54) \\
4.3 \%\end{array}$ & $\begin{array}{c}91 \\
(0.35) \\
7.7 \%\end{array}$ & $\begin{array}{c}194 \\
(0.70) \\
6.8 \%\end{array}$ & $\begin{array}{c}199 \\
(0.92) \\
5.7 \%\end{array}$ & $\begin{array}{c}333 \\
(2.44) \\
5.4 \%\end{array}$ & $\begin{array}{c}324 \\
(1.83) \\
5.4 \%\end{array}$ \\
\hline Mining & $\begin{array}{c}358 \\
(1.84) \\
25.7 \%\end{array}$ & $\begin{array}{c}450 \\
(2.3) \\
20.8 \%\end{array}$ & $\begin{array}{c}209 \\
(1.20) \\
17.7 \%\end{array}$ & $\begin{array}{c}447 \\
(4.34) \\
15.6 \%\end{array}$ & $\begin{array}{c}509 \\
(5.31) \\
14.5 \%\end{array}$ & $\begin{array}{c}783 \\
(12.22) \\
12.7 \%\end{array}$ & $\begin{array}{c}781 \\
(9.65) \\
13 \%\end{array}$ \\
\hline Other & $\begin{array}{c}222 \\
(0.93) \\
15.9 \%\end{array}$ & $\begin{array}{c}275 \\
(0.75) \\
12.7 \%\end{array}$ & $\begin{array}{c}148 \\
(0.32) \\
12.5 \%\end{array}$ & $\begin{array}{c}529 \\
(1.18) \\
18.5 \%\end{array}$ & $\begin{array}{c}755 \\
(2.02) \\
21.5 \%\end{array}$ & $\begin{array}{l}1,207 \\
(5.34) \\
19.6 \%\end{array}$ & $\begin{array}{l}1,123 \\
(4.38) \\
18.7 \%\end{array}$ \\
\hline $\begin{array}{l}\text { Commercial } \\
\text { services }\end{array}$ & $\begin{array}{c}20 \\
(0.13) \\
1.4 \%\end{array}$ & $\begin{array}{c}38 \\
(0.17) \\
1.8 \%\end{array}$ & $\begin{array}{c}33 \\
(0.09) \\
2.8 \%\end{array}$ & $\begin{array}{c}86 \\
(0.24) \\
3 \%\end{array}$ & $\begin{array}{c}77 \\
(0.36) \\
2.2 \%\end{array}$ & $\begin{array}{c}124 \\
(0.86) \\
2 \%\end{array}$ & $\begin{array}{c}87 \\
(0.50) \\
1.4 \%\end{array}$ \\
\hline Trading & $\begin{array}{c}117 \\
(0.93) \\
8.4 \%\end{array}$ & $\begin{array}{c}171 \\
(0.82) \\
7.9 \%\end{array}$ & $\begin{array}{c}145 \\
(0.52) \\
12.3 \%\end{array}$ & $\begin{array}{c}312 \\
(1.16) \\
10.9 \%\end{array}$ & $\begin{array}{c}328 \\
(1.82) \\
9.3 \%\end{array}$ & $\begin{array}{c}668 \\
(4.91) \\
10.9 \%\end{array}$ & $\begin{array}{c}461 \\
(3.41) \\
7.7 \%\end{array}$ \\
\hline Total $^{*}$ & $\begin{array}{l}1,396 \\
(0.84)\end{array}$ & $\begin{array}{l}2,165 \\
(0.92)\end{array}$ & $\begin{array}{l}1,185 \\
(0.42)\end{array}$ & $\begin{array}{l}2,865 \\
(1.10)\end{array}$ & $\begin{array}{l}3,512 \\
(1.66)\end{array}$ & $\begin{array}{l}6,147 \\
(2.75)\end{array}$ & $\begin{array}{l}5,994 \\
(3.53)\end{array}$ \\
\hline
\end{tabular}

Source: See note 20.

* Includes Chinese and indigenous Indonesian incorporated firms with headquarters in the Netherlands Indies.

It is easy to discern that the database figures suggest a share of Dutch investment that is higher than the $70 \%$ that is generally cited in the literature for Dutch investment (Callis, 1942: 28-34). In Table 6 the lowest figure is 79.6\% for 1940 and the highest one an improbable $95.1 \%$ for 1910. Although this share declined before 1940, it is far too high. Inevitably we conclude that foreign companies are often included in the category Dutch companies. Callis shows that in 1937 British investment was \$200 million, if we would use an exchange rate of the gold standard of $f 2.5$ per $\$ 1$, this means that some $f 500$ million of British capital was invested in the Netherlands Indies. Investment by other countries then amounts to $f 427.5$ million in current prices, which is also higher than as derived from the database (Callis, 1942: 34). Foreign nonDutch investment was particularly prominent in the rubber industry, which was popular among the indigenous Indonesian entrepreneurs not incorporated under Dutch law. In 1914 39\% of foreign invested capital in rubber was Dutchowned, dominated by British capital. By 1930 the Dutch share had risen to 
$38 \%, 28 \%$ was British investment and $16.5 \%$ of American origin. In the tea and palm oil industry investment by third countries was also popular (Manschot, 1932: 272-273; Taselaar, 1998: 45; Touwen, 2011: 111). The British held 40\% of the Royal Dutch-Shell subsidiaries (Callis, 1943: 26).

The final topic to be discussed here is the distribution of investment by industry. Although the statistics in Table 7 contain domestic investment by Chinese and indigenous Indonesians as well, it is relevant to show the developments of these investments in real prices and to see which industries had a larger share in total equity than with respect to numbers of enterprises. If we compare the shares per industry from Table 1 we can see immediately that the share of finance and mining companies in total companies was relatively small. For finance this was 4\% in 1910 and 5\% in 1940 and for mining it was $9.6 \%$ in 1910 and $3.8 \%$ in 1940 . As a share of total equity however, these companies were more important. Already in 1910 the share of finance companies was $10.3 \%$ of total equity and in 1940 this had increased to an impressive $24.5 \%$. The share of equity in the mining industry, however, declined from a notable $24.5 \%$ in 1910 to around half this figure, $12.2 \%$ in 1940 . Differences in other industries were less spectacular, although the share of equity in commercial services was rather low compared with their number of total companies.

\section{Conclusion}

In this contribution I show the development of private foreign investment in the Netherlands Indies in the late colonial period. I use a database with information from the Handboek voor cultuur-en handelsondernemingen in Nederlandsch-Indië as main source and I trace the development for seven individual years between 1910 and 1940. I focus on numbers of companies, their origin, the industries in which they operated, the chronology of incorporation and the firms' equity.

One characteristic of foreign investment in the Netherlands Indies is that the Dutch presence was truly overwhelming, although it took some time before Dutch private investors became enthusiastic. Eventually half of total Dutch foreign investment was undertaken in the Netherlands Indies, which was around one-quarter of total Dutch investment. The share of British and third-country companies in the database was far lower than what is generally assumed in the literature. This suggests that foreign companies were often incorporated as Netherlands Indies investment.

Another distinction is that the majority of the companies was relatively young, although finance was dominated by older companies, that often date from the nineteenth century. On the whole, the majority of the companies was founded during the first quarter of the twentieth century. It was in this period that the total number of foreign companies active in the Netherlands Indies reached its peak. After 1920 numbers gradually declined and during the economic depression of the 1930s more companies went bankrupt. Only 
in 1940 was there some recovery in numbers of firms. Another salient characteristic is that there was a large number of companies with equity less than $f 500,000$ and a slightly increasing share of companies with much more equity. The economy in the Netherlands Indies was defined by a large number of small companies and a few large companies.

Overall, the share of agricultural companies remained the largest. As a share of total equity finance was only second to agriculture. Although only a small number of companies were active in the mining industry, the large oil companies enhanced the importance of this industry significantly. Trading companies in fact did not strengthen their position in the course of time. By the outbreak of the Pacific War, exports of unprocessed agricultural goods and minerals formed the chief targets of investment.

\section{Bibliography}

Arndt, H.W. 'Banking in hyperinflation', Bulletin of Indonesian Economic Studies, Vol. 5, 1966, pp. 45-70.

Booth, Anne. The Indonesian economy in the nineteenth and twentieth centuries: A history of missed opportunities. London: Macmillan, 1998.

Bosch, K.D. De Nederlandse beleggingen in de Verenigde Staten. Amsterdam: Elsevier, 1948.

Callis, Helmut G. 'Capital investment in Southeast Asia and the Philippines', The ANNALS of the American Academy of Political and Social Science, Vol. 22, 1943, pp. 22-31.

Callis, Helmut G. Foreign capital in Southeast Asia. New York: Institute of Pacific Relations, 1942.

Campo, J.N.F.M. à. 'Strength, survival and success; A statistical profile of corporate enterprise in colonial Indonesia 1893-1913', Jahrbuch für Wirtschaftsgeschichte, Vol. 46, 1995, pp. 45-74.

Campo, J.N.F.M. à. 'The rise of corporate enterprise in colonial Indonesia, 18931913', in: J. Thomas Lindblad (ed.), Historical foundations of a national economy in Indonesia, 1880s-1990s. Amsterdam: North-Holland, 1996, pp. 71-94.

Creutzberg, P. Changing Economy in Indonesia. Vol. 3. Expenditure on fixed assets. Amsterdam: Royal Tropical Institute, 1977.

Derksen, J.B.D. \& J. Tinbergen. Berekeningen over de economische betekenis van Nederlandsch-Indië voor Nederland. The Hague: Centraal Bureau voor de Statistiek, 1941.

Dick, Howard. 'The emergence of a national economy, 1808-1990s', in: J. Thomas Lindblad (ed.), Historical foundations of a national economy in Indonesia, 1880s-1990s. Amsterdam: North-Holland, 1996, pp. 21-52.

Dick, Howard et al. [= Howard Dick, Vincent J.H. Houben, J. Thomas Lindblad \& Thee Kian Wie]. The emergence of a national economy in Indonesia: An economic history of Indonesia, 1800-2000. Crows Nest, NSW: Allen \& Unwin, 2002, pp. 153-193.

Don, Henk \& Johan Verbruggen. 'Models and methods for economic policy; 60 years of evolution at CPB', СРB Discussion Paper, No. 55, The Hague, 2006.

Eng, Pierre van der. Economic benefits from colonial assets: the case of the Netherlands 
and Indonesia 1870-1958. Research Memorandum, Groningen, 1998.

Eng, P. van der. 'Exploring exploitation: The Netherlands and colonial Indonesia 1870-1940', Revista de Historia Económica, Vol. 16, 1998, pp. 291-321.

Eng, Pierre van der. 'Indonesia's growth performance in the twentieth century', in: Angus Maddison, D.S. Prasado Rao \& William F. Shepherd (eds), The Asian economies in the twentieth century. Cheltenham: Elgar, 2002, pp. 143-179.

Fernando, M.R. \& David Bulbeck. Chinese economic activity in Netherlands India. Selected translations from the Dutch. Singapore: Institute of Southeast Asian Studies, 1992.

Helfferich, Emil. Die Niederländisch-Indische Kulturbanken. Jena: Fischer, 1914.

Korthals Altes, W.L. Tussen cultures en kredieten. Een institutionele geschiedenis van de Nederlandsch-Indische Handelsbank en Nationale Handelsbank 1863-1964. Amsterdam: NIBE-SVV, 2004.

Leeuwen, Bas van. 'Human capital and economic growth in India, Indonesia, and Japan', PhD thesis, Utrecht University, 2007.

Lindblad, J. Thomas. 'Economische aspecten van de Nederlandse expansie in de Indonesische archipel', in: J. van Goor (ed.), Imperialisme in de marge, De afgrond van Nederlands-Indië. Utrecht: HES, 1986, pp. 227-266.

Lindblad, J. Thomas. 'Economic aspects of the Dutch expansion in Indonesia, 18701914', Modern Asian Studies Vol. 23,1989, pp. 1-24.

Lindblad, J. Thomas. 'The economic relationship between the Netherlands and colonial Indonesia, 1870-1940', in: J.L van Zanden (ed.) The economic development of the Netherlands since 1870. Cheltenham: Elgar, 1996, pp. 109-119.

Lindblad, J. Thomas. Foreign investment in Southeast Asia in the twentieth century. London: Macmillan, 1998.

Lindblad, J. Thomas. Bridges to new business. The economic decolonization of Indonesia. Leiden: KITLV Press, 2008.

Lindblad, J. Thomas. 'Booming business in colonial Indonesia: Corporate strategy and profitability during the 1920s', paper presented at the 23rd conference of the International Association of Historians of Asia, Alor Star, Malaysia, August 2014 [www.colonialbusinessindonesia.nl].

Locher-Scholten, Elsbeth. 'Dutch expansion in the Indonesian archipelago around 1900 and the imperialism debate', Journal of Southeast Asian Studies, Vol. 25, 1994, pp. 91-111.

Lynden, C.D.A. van. Directe investeeringen in het buitenland. 's-Gravenhage: Boucher, 1945.

Manschot, H.J. 'De invloed van het buitenlandsch kapitaal op de ontwikkeling van de cultures ter Oostkust van Sumatra, 'Economisch-Statistische Berichten, Vol. 17, 1932, pp. 272-273.

Renooij, Dirk Cornelis. De Nederlandse emissiemarkt. Amsterdam: De Bussy, 1951.

Roos, F. de \& W.J. Wieringa. Een halve eeuw rente in Nederland. Schiedam: Levensverzekering-maatschappij HAV Bank, 1953.

Sluyterman, Keetie, E. Dutch enterprise in the twentieth century. Business strategies in a small open economy. London: Routledge, 2005.

Soest, Jan Jacob van. Een bijdrage tot de kennis van de beteekenis der Nederlandsche beleggingen in buitenlandsche fondsen voor de volkswelvaart. Utrecht: Kermink, 1938.

Taselaar, Arjen. De Nederlandse koloniale lobby: Ondernemers en de Indische politiek, 
1914-1940. Leiden: Research School CNWS, 1998.

Touwen, Jeroen. Extremes in the archipelago: Trade and economic development in the outer islands of Indonesia, 1900-1942. Leiden: KITLV, 2001.

Wilkins, Mira. 'The free-standing Company, 1870-1914. An important type of British foreign direct investment', Economic History Review, Vol. 41, 1988, pp. 259-282.

Zanden, Jan Luiten van \& Daan Marks, An economic history of Indonesia, 1800-2010. London: Routledge, 2012.

\section{Websites}

Colonial Business Indonesia (CBI): CBI Database ID', at www. colonialbusinessindonesia.nl.

Centraal Bureau voor de Statistiek (Central Bureau of Statistics): 'Consumentenprijzen; prijsindex $1900=100$ ', at www.statline.cbs.nl. 